\title{
Effects of Anesthesia and Anesthetic Techniques on Metastasis of Lung Cancers: A Narrative Review
}

\section{Zhenghuan Song \\ Jing Tan}

Department of Anesthesiology, Jiangsu Cancer Hospital \& Jiangsu Institute of Cancer Research \& The Affiliated Cancer Hospital of Nanjing Medical University, Nanjing, Jiangsu Province, People's Republic of China
Correspondence: Jing Tan

Department of Anesthesiology, Jiangsu Cancer Hospital \& Jiangsu Institute of

Cancer Research \& The Affiliated Cancer Hospital of Nanjing Medical University, 42

Baiziting, Xuanwu Section, Nanjing, Jiangsu Province, People's Republic of China

Tel +86-02583284765

Email tanjing@njmu.edu.cn
Purpose: Tumor recurrence and metastasis are essential for the mortality and morbidity of cancer. Surgical resection of solid tumors is the conventional treatment approach for malignant tumors. However, even after undergoing radical surgery, certain patients develop local or distant metastasis, which may contribute to treatment failure. Anesthesia and anesthetic techniques are widely used in the perioperative period. Emerging evidence indicates that anesthetics influence tumor recurrence and metastasis. Therefore, the current review summarizes the effects of anesthesia and anesthetic techniques on tumor recurrence and lung metastasis.

Methods: Relevant literature was retrieved from the following databases: Medline/PubMed, CNKI and Wanfang. A total of 109 articles were selected and analyzed in this research.

Results: (1) A variety of intravenous anesthetics may affect metastasis or tumor growth, though the evidence is contradictory and inconsistent, and the clinical data are still inconclusive. (2) Volatile anesthetics have proinflammatory effects and may have direct and indirect effects on the survival of cancer cells. (3) Although the relevant clinical data are limited, there is strong evidence in vitro that local anesthetics have a protective effect on cancer recurrence. (4) No mode of anesthesia has been determined to be beneficial to patients with cancer, but clinical studies are currently recommended for anesthesia modality and composite use.

Conclusion: Available data suggest that anesthesia and anesthetic techniques might play an important role in tumor progression and lung metastasis, the understanding of which will help in designing more effective management of the tumor and attaining fewer side effects. Keywords: anesthesia, anesthetics, tumor, recurrence, lung metastasis

\section{Introduction}

Malignant cancer is a leading cause of mortality worldwide. The majority of deaths result from distant tumor metastasis. ${ }^{1,2}$ It is expected that there will be 28.4 million new cases of cancer in $2040 .^{3}$ Surgical resection is the main effective option for early-stage cancer at present. ${ }^{4}$ Approximately $56-91 \%$ of patients with lung, breast, bladder, and colorectal cancer will undergo surgery. ${ }^{5}$ However, surgery is one of the most important factors affecting cancer progression and metastases formation, and the process of tumor manipulation might result in increased tumor cells being released into the vasculature and the promotion of metastasis. ${ }^{6}$ Despite advances in medical techniques (eg, radiation therapy, chemotherapy, targeted therapy and other new strategies) leading to remarkable progress in the treatment of cancer, 
tumor metastasis is a major challenge of cancer therapy, and the lungs are the most frequently identified site of systemic metastases. ${ }^{7,8}$ Anesthesia management is a crucial part of the surgical process. Current research has revealed that modern anesthesia not only has a good anesthetic effect but also potentially influences the interactions between tumor cells, including the immune system and tumor microenvironment. ${ }^{9-12}$ For example, volatile anesthetics and opioids can suppress cell-mediated immunity and promote cancer cell proliferation. ${ }^{13,14}$ Thiopental and ketamine have been implicated in increasing lung retention and lung metastasis of tumor cells via diminished natural killer cell function. ${ }^{12}$ Therefore, understanding the molecular mechanism underlying these effects is critically important to help guide treatment choices by anesthetists.

In this review, we aim to provide additional, valuable information regarding the role of anesthesia and anesthetic techniques in different aspects of lung tumor metastasis and recurrence.

\section{Search Strategy}

Electronic databases were searched until September 2021 using a string of medical subject heading terms or related terms. The primary keywords used in the searches were as follows: "anesthesia and metastases", "lung tumor", "anesthetic agents and cancer", "inhalation anesthesia and cancer", "cancer recurrence" and "anesthetic technique and cancer". PubMed was used as a search engine for the Medline database and as the main source of information for this paper. Furthermore, the China National Knowledge Infrastructure (CNKI) and Wanfang Database were also searched for relevant articles. The language was restricted to English and Chinese. The article type included review articles, cell animal experiments, observational studies and clinical trials. In addition, we searched related articles in the reference lists of the included articles. A total of 109 articles were selected and analyzed in this research. Then, two authors reviewed these retrieved articles for suitability.

\section{Anesthetics Promote Lung Metastasis and Tumor Recurrence}

Anesthetics are a heterogeneous group of drugs with multiple functions and mechanisms of action. Previous studies have reported that the choice of anesthetics can affect the prognosis of patients undergoing cancer surgery. The following section summarizes common anesthetics and their effects.

\section{Intravenous Anesthetics}

Intravenous anesthetics are widely used for general anesthesia, and they primarily target the central nervous system, including sedation, analgesia and muscle relaxants. Recent studies report that intravenous anesthesia affects tumor recurrence and metastasis through complex mechanisms.

\section{Propofol}

Propofol (2,6-diisopropylphenol) is commonly used for the induction and maintenance of general anesthesia. It is characterized by rapid induction and quick recovery. Studies report that propofol plays a role in cancer progression by modulating the expression of multiple signaling pathways; thus, studies have been conducted to explore the potential mechanisms. ${ }^{15}$ In addition, preclinical and clinical studies have been conducted to explore the role of propofol in cancer progression (selected studies are summarized in Table 1).

\section{In vivo Studies}

Mice administered propofol anesthesia presented with less lung metastasis after primary tumor resection than mice administered sevoflurane. ${ }^{16}$ Findings from nude mouse model studies show that propofol inhibits the growth of syngeneic 4T1 and human MDA-MB-231 breast cancer xenografts. $^{15,17}$ In addition, propofol downregulates the expression of E-cadherin and $\beta$-catenin in metastatic tumor tissues and inhibits lung metastasis of MADB106 tumor cells. $^{18,19}$

\section{In vitro Studies}

Propofol inhibits the proliferation, migration and invasion of cancer cells and promotes apoptosis by regulating several signaling pathways and the expression of noncoding RNAs in vitro. For example, propofol inhibits the invasion and metastasis of lung cancer by downregulating the expression of matrix metalloproteinase (MMP)-2 and MMP-9. ${ }^{20}$ Moreover, propofol inhibits the proliferation and metastasis of lung cancer H460 cells by inducing endoplasmic reticulum stress and the JNK signaling pathway. ${ }^{21}$ Propofol downregulates p38MAPK signal transduction to inhibit cancer cell migration and invasion. ${ }^{22}$ In addition, propofol upregulates the expression of apoptosis-related proteins by modulating the activities of miRNAs. For instance, propofol 
Table I Effects of Propofol on Lung Metastasis of Tumor Cells

\begin{tabular}{|c|c|c|c|c|}
\hline Title & Author & Year & Type & Significant Result \\
\hline $\begin{array}{l}\text { Effects of propofol on pulmonary metastasis of } \\
\text { intravenous injected tumor cells and expressions of } \\
\text { MTAI and Wntl in rats. }{ }^{19}\end{array}$ & $\begin{array}{l}\text { Zhang } \\
\text { Yet al }\end{array}$ & 2014 & $\begin{array}{l}\text { In vivo } \\
\text { study }\end{array}$ & $\begin{array}{l}\text { Propofol could inhibit pulmonary metastasis of } \\
\text { intravenous tumor cells in a dose-dependent manner } \\
\text { and down-regulate the expression of MTAI and Wntl } \\
\text { in metastatic tumor tissues. }\end{array}$ \\
\hline $\begin{array}{l}\text { Effects of propofol on pulmonary metastasis of } \\
\text { intravenously injected MADBI06 tumor cells and } \\
\text { expression of E-cadherin and } \beta \text {-catenin in rats. }{ }^{18}\end{array}$ & $\begin{array}{l}\text { Wang } \\
\text { Wet al }\end{array}$ & 2015 & $\begin{array}{l}\text { In vivo } \\
\text { study }\end{array}$ & $\begin{array}{l}\text { Propofol can down-regulate the expression of } \\
\text { E-cadherin and } \beta \text {-catenin in metastatic tumor tissues by } \\
\text { inhibiting Wnt/ } \beta \text {-catenin pathway, and inhibit lung } \\
\text { metastasis of intravenous MADBI06 tumor cells in a } \\
\text { dose-dependent manner. }\end{array}$ \\
\hline $\begin{array}{l}\text { Distinct effects of general anesthetics on lung metastasis } \\
\text { mediated by IL-6/JAK/STAT3 pathway in mouse } \\
\text { models. }{ }^{17}\end{array}$ & $\begin{array}{l}\text { Li R } \\
\text { et al }\end{array}$ & 2020 & $\begin{array}{l}\text { In vivo } \\
\text { study }\end{array}$ & $\begin{array}{l}\text { In syngeneic mouse } 4 \mathrm{TI} \text { and human MDA-MB23I breast } \\
\text { cancer xenograft model, surgical resection of primary } \\
\text { tumor in mice under sevoflurane anesthesia resulted in } \\
\text { more lung metastasis than propofol. }\end{array}$ \\
\hline $\begin{array}{l}\text { Suppression of cell invasion and migration by propofol } \\
\text { are involved in down-regulatin matrix } \\
\text { metalloproteinase- } 2 \text { and p38 MAPK signaling in A549 } \\
\text { human lung adenocarcinoma epithelial Cells. }{ }^{22}\end{array}$ & $\begin{array}{l}\text { Wu KC } \\
\text { et al }\end{array}$ & 2012 & $\begin{array}{l}\text { In vitro } \\
\text { study }\end{array}$ & $\begin{array}{l}\text { Propofol has a variety of anti-metastatic activities in } \\
\text { A549 cells and can inhibit the migration and invasion of } \\
\text { A549 cells. The possible signal pathway may be that it } \\
\text { inhibits MMP-2 and MMP-9 and stimulates TIMPI and } \\
\text { TIMP2 by blocking the expression of MMP- } 2 \text { and- } \\
\text { 9mRNA. }\end{array}$ \\
\hline $\begin{array}{l}\text { Propofol Inhibits Lung Cancer A549 Cell Growth and } \\
\text { Epithelial-Mesenchymal Transition Process by } \\
\text { Upregulation of MicroRNA-1284. }\end{array}$ & $\begin{array}{l}\text { Liu WZ } \\
\text { et al }\end{array}$ & 2018 & $\begin{array}{l}\text { In vitro } \\
\text { study }\end{array}$ & $\begin{array}{l}\text { Propofol could inhibit cell viability, migration, invasion, } \\
\text { and the EMT process in lung cancer cells by regulation } \\
\text { of miR- } 1284 \text {. }\end{array}$ \\
\hline $\begin{array}{l}\text { Propofol suppresses growth, migration and invasion of } \\
\text { A549 cells by down-regulation of miR- } 372 .^{25}\end{array}$ & $\begin{array}{l}\text { Sun } \mathrm{H} \\
\text { et al }\end{array}$ & 2018 & $\begin{array}{l}\text { In vitro } \\
\text { study }\end{array}$ & $\begin{array}{l}\text { Propofol inhibits the growth, migration and invasion of } \\
\text { lung cancer } A 549 \text { cells by down-regulating miR372 and } \\
\text { inactivating Wnt/ } \beta \text {-catenin and mTOR pathways. }\end{array}$ \\
\hline $\begin{array}{l}\text { Propofol induces apoptosis of non-small cell lung cancer } \\
\text { cells via ERKI/2-dependent upregulation of PUMA. }{ }^{26}\end{array}$ & $\begin{array}{l}\text { Xing SG } \\
\text { et al }\end{array}$ & 2018 & $\begin{array}{l}\text { In vitro } \\
\text { study }\end{array}$ & $\begin{array}{l}\text { Propofol inhibits the survival and induces apoptosis of } \\
\text { A549 cells in a dose-dependent manner in vitro. The } \\
\text { mechanism may be that propofol inhibits cell survival } \\
\text { and induces apoptosis through ERKI/2-dependent } \\
\text { PUMA signaling pathway. }\end{array}$ \\
\hline $\begin{array}{l}\text { Propofol suppresses invasion of human lung cancer } \\
\text { A549 cells by down-regulating aquaporin-3 and matrix } \\
\text { metalloproteinase- } 9 .^{20}\end{array}$ & $\begin{array}{l}\text { Ye HJ } \\
\text { et al }\end{array}$ & 2016 & $\begin{array}{l}\text { In vitro } \\
\text { study }\end{array}$ & $\begin{array}{l}\text { Treatment with } 50 \text { and } 100 \mu \mathrm{mol} / \mathrm{L} \text { propofol for } 24 \mathrm{~h} \\
\text { significantly inhibits the number of invading cells by } \\
\text { down-regulating the expression of AQP-3 and MMP-9 in } \\
\text { A549 cells. }\end{array}$ \\
\hline $\begin{array}{l}\text { Propofol inhibits lung cancer cell viability and induces } \\
\text { cell apoptosis by upregulating microRNA- } 486 \\
\text { expression. }{ }^{30}\end{array}$ & $\begin{array}{l}\text { Yang } N \\
\text { et al }\end{array}$ & 2017 & $\begin{array}{l}\text { In vitro } \\
\text { study }\end{array}$ & $\begin{array}{l}\text { Propofol increased the level of miR- } 486 \text { in } \mathrm{HI} 299 \text { and } \\
\mathrm{HI} 792 \text { cells in a dose-dependent manner. Propofol } \\
\text { decreased the cell survival rate, but increased the } \\
\text { percentage of apoptotic cells and the protein expression } \\
\text { of FOXOI, FOXO3, Bim, pre-caspases and activated } \\
\text { caspases. }\end{array}$ \\
\hline $\begin{array}{l}\text { Propofol suppresses LPS-induced nuclear accumulation } \\
\text { of HIF-Ialpha and tumor aggressiveness in non-small cell } \\
\text { lung cancer. }{ }^{23}\end{array}$ & $\begin{array}{l}\text { Yang N } \\
\text { et al }\end{array}$ & 2017 & $\begin{array}{l}\text { In vitro } \\
\text { study }\end{array}$ & $\begin{array}{l}\text { Inflammation stimulated by endotoxin enhances the } \\
\text { function of HIF-I } \alpha \text { by increasing the expression level, } \\
\text { protein stability and nuclear localization of NSCLC cells, } \\
\text { which leads to the increase of markers and mediators of } \\
\text { migration and invasion. Propofol inhibited all these } \\
\text { effects by inhibiting hypoxia inducible factor-I } \alpha \text {. }\end{array}$ \\
\hline
\end{tabular}

(Continued) 
Table I (Continued).

\begin{tabular}{|l|l|l|l|l|}
\hline Title & Author & Year & \multicolumn{1}{|c|}{ Type } & \multicolumn{1}{|c|}{ Significant Result } \\
\hline $\begin{array}{l}\text { Propofol induces endoplasmic reticulum (ER) stress and } \\
\text { apoptosis in lung cancer cell H460. }\end{array}$ & $\begin{array}{l}\text { Cui WY } \\
\text { et al }\end{array}$ & 2014 & $\begin{array}{l}\text { In vitro } \\
\text { and in } \\
\text { vivo }\end{array}$ & $\begin{array}{l}\text { Propofol inhibits proliferation and induces apoptosis in } \\
\text { H460 cells and inhibits tumor growth in vivo. propofol } \\
\text { acts as a positive regulator in ER stress and JNK } \\
\text { signaling pathway. }\end{array}$ \\
\hline $\begin{array}{l}\text { Impact of anesthetic agents on overall and recurrence- } \\
\text { free survival in patients undergoing esophageal cancer } \\
\text { surgery. }\end{array}$ & $\begin{array}{l}\text { Jun I.J } \\
\text { et al }\end{array}$ & 2017 & $\begin{array}{l}\text { Clinical } \\
\text { study }\end{array}$ & $\begin{array}{l}\text { Intravenous anesthesia with propofol (TIVA)was } \\
\text { associated with better postoperative survival rates. }\end{array}$ \\
\hline
\end{tabular}

induces apoptosis of lung cancer cells by upregulating the expression of miRNA-486, FOXO1 and FOXO3 (fork box, $\mathrm{O} 1$ and 3), BIM (Bcl-2 cell death interaction mediator) and caspase-3. ${ }^{23}$ Furthermore, it downregulates the expression of miR-372 to promote apoptosis of the lung cancer cell line A549. In addition, the expression of miR-1284 in lung cancer cells and A549 cells was significantly upregulated when the cells were cocultured with therapeutic concentrations of propofol, thus inhibiting the migration, invasion and epithelial-mesenchymal transformation of A549 tumor cells. ${ }^{23-25}$ Moreover, propofol inhibits the survival and induces the apoptosis of A549 cells through the extracellular regulated protein kinase (ERK)1/2-dependent PUMA signaling pathway. ${ }^{26}$

Tumor hypoxia is a characteristic feature of the tumor microenvironment and promotes metastasis of several cancer types. Analysis of clinical samples showed that hypoxia inducible factor-1 $\alpha$ (HIF-1 $\alpha$ ) is abnormally expressed in non-small-cell lung cancer (NSCLC). ${ }^{27-29}$ Increased expression of HIF-1 $\alpha$ is correlated with poor prognosis. Propofol significantly decreases HIF-1 $\alpha$ and ROS levels induced by lipopolysaccharide (LPS) in a dose-dependent manner. Propofol reduces the protein stability and nuclear localization of HIF-1 $\alpha$; thus, it antagonizes the effect of LPS on the activation of HIF-1 $\alpha$ and regulates the response of cells to an inflammation-related microenvironment. ${ }^{30}$ Therefore, propofol can potentially reduce the metastasis of tumor cells.

In summary, findings from previous in vitro studies indicate that propofol inhibits the growth and metastasis of tumors, although the mechanisms have not been fully elucidated.

Clinical Studies on the Effect of Propofol on Tumors Only a few clinical studies have explored pulmonary metastasis after tumor resection. Notably, this was a retrospective study comprising lung cancer patients who reported better outcomes after TIVA than after inhalation anesthesia. ${ }^{31}$ A study explored the percentage of CD4(+) and $\mathrm{CD} 28(+)$ cells and the ratio of interferon- $\gamma /$ interleukin4 in patients with non-small-cell lung cancer after lobectomy. The findings showed that propofol promotes the activation and differentiation of $\mathrm{T}$ helper cells in peripheral blood, and the activation and differentiation of $\mathrm{T}$ helper cells plays an important role in perioperative antitumor and anti-infective immunity, indicating that propofol may have an antitumor effect. ${ }^{32}$ Multicenter prospective clinical studies should be conducted to explore the effect of propofol anesthesia on lung metastasis.

In general, propofol has been shown to potently reduce the viability of tumor cells and postpone lung metastasis in vivo and in vitro. Its function may be mediated by regulating factors related to apoptosis, $\mathrm{T}$ helper cells, and some signaling pathways. These results show a new efficacy of propofol in addition to sedation and hypnosis and provide a possible strategy for tumor treatment.

\section{Etomidate}

In vitro Studies on the Effect of Etomidate on Tumors A previous study reported that the activity of MMP-2 was reduced after treatment of A549 cells with etomidate for $48 \mathrm{~h}$. In addition, etomidate downregulated the expression of PKC, MMP-7, MMP-1, MMP-9 and P-P-38, whereas the expression of RAS, PI3K and phosphorus extracellular signal-related kinases was upregulated, thus inhibiting the migration and invasion of A549 cells. $^{33}$

\section{Clinical Studies of the Effect of Etomidate on Tumors} Intraoperative etomidate stabilizes hemodynamics and maintains the levels of $\mathrm{CD} 4+$ and $\mathrm{CD} 8+$ cells in patients with lung adenocarcinoma, ${ }^{34}$ which may be beneficial in preventing tumor metastasis. However, only a few clinical studies and clinical retrospective studies have explored the effect of etomidate on the clinical outcomes of cancer 
patients. Therefore, further studies on etomidate using animal models and clinical observation of different cancer types should be conducted to explore the effect of etomidate.

\section{Opioids}

In addition to their analgesic properties, opioids have several nonanalgesic effects. ${ }^{35}$ Opioids also act on tumor and immune cells, and previous studies have reported inhibition of growth in various tumor cell types by opioids. However, studies have reported both positive and negative effects of mu agonists on tumor growth; hence, further studies should be conducted.

\section{In vivo Studies on the Effects of Opioids on Tumors} Opioids induce the proliferation of tumor cells in a concentration- and time-dependent manner. Low concentrations or single doses of opioids can stimulate tumor growth. In contrast, high concentrations or chronic opioid use inhibit tumor growth. ${ }^{36}$

The $\mu$ receptor is overexpressed in some non-small-cell lung cancer cells. ${ }^{37}$ Morphine can activate the $\mu$-opioid receptor (MOR) in tumor cells, induce phosphorylation of epidermal growth factor receptor (EGFR), and promote activation of downstream MAPK/ERK Akt, ultimately promoting cell proliferation and invasion. Morphine upregulates the expression of EGFR and MOR in lung cancer and promotes the growth of non-small-cell lung cancer. EGFR in human lung cancer indicates that morphine has a growth-promoting effect in lung cancer, thus increasing the risk of micrometastasis. ${ }^{38}$

Silencing of the $\mu$ receptor using a knockout technique can significantly reduce opioid-induced tumor growth in vitro. ${ }^{39}$ Mathew et $\mathrm{al}^{40}$ reported that the expression of the $\mu$-opioid receptor in NSCLC cells was 5-10 times higher than that in normal lung tissue. Application of the $\mu$-opioid receptor agonist morphine promoted the growth of Lewis lung cancer cells, whereas use of $\mu$-opioid receptor blockers or inhibition of $\mu$-opioid receptors inhibited the proliferation and migration of $50 \%$ to $80 \%$ of Lewis lung cancer cells. Furthermore, the study explored the relationship between opioid receptors and tumor metastasis, and the findings showed that opioid receptor knockout mice treated with the opioid receptor antagonist naltrexone had reduced lung cancer metastasis.

Methylnaltrexone (MNTX) is a selective peripheral $\mu$ receptor blocker. Use of MNTX shows similar results as naltrexone. Continuous infusion of MNTX after tumor formation significantly reduced primary tumor growth and lung metastasis. ${ }^{40-42}$

\section{In vitro Studies on the Effect of Opioids on Tumors} Although morphine is the classical opioid "reference molecule", several other semisynthetic and synthetic opioids are clinically used for the management of pain in patients. Notably, different opioids have different effects on tumor metastasis.

Some studies have explored the inhibition of natural killer cell activity by fentanyl, which is important for abrogating metastasis. ${ }^{43,44}$

\section{Clinical Studies on the Effects of Opioids on Cancer} Clinical studies have been conducted to explore the association between opioid use and an increased risk of tumor recurrence. ${ }^{45,46}$ Recent studies have reported that high doses of opioids after surgery in early NSCLC patients increased the risk of tumor recurrence 5 years after videoassisted thoracoscopic surgery (VATS) ${ }^{47}$

A single-center retrospective study explored the effect of postoperative opioid use on overall survival (OS) and disease-free survival (DFS) in early-stage NSCLC patients. The results showed a significant decrease in overall survival in the opioid-using group compared to the control group. ${ }^{48}$

Similarly, Maher et al reported that postoperative opioid use increased cancer recurrence and reduced DFS in 99 patients with stage I and IIa non-small-cell lung cancer. $^{47}$

In contrast, a previous study reported that there was no significant correlation between total opioid consumption and long-term recurrence or survival in patients after radical resection of lung cancer. ${ }^{49}$

Inconsistencies remain as to whether the opioids only inhibit or also promote lung cancer growth. In summary, these results indicate that morphine can stimulate the proliferation of cells with high MOR expression. For clinical implications, MOR antagonists may be worth investigating further as potential therapeutic agents in cancer therapy.

\section{Ketamine}

Ketamine is a noncompetitive blocker of nonsteroidal receptors and is the only intravenous anesthetic with definite analgesic effects. Ketamine exerts immunoregulatory effects on macrophages, lymphocytes and mast cells. Notably, $10 \mathrm{mg} / \mathrm{kg}$ ketamine inhibits NK cell activity in vitro. $^{44}$ 


\section{In vivo Studies on the Effects of Ketamine on Cancer}

A study using a rat model reported that administration of ketamine at a concentration 2-3 times greater than the clinical dose inhibited dendritic cell-mediated T-cell activation. ${ }^{50}$ Previous studies explored the effects of ketamine on NK cell activity and tumor cell metastasis in mice, and the findings showed that ketamine increased the lung metastasis ability of MADB106 cells and significantly inhibited the activity and proliferation of NK cells. $^{12}$

Clinical Studies on the Effects of Ketamine on Cancer Connolly et al explored the relationship between the tumor-specific genome and intraoperative opioid administration and the survival rate of patients with lung cancer. The findings showed that intraoperative opioid exposure is associated with worse overall survival, whereas ketamine exposure is associated with improved recurrence-specific survival in patients with early-stage lung adenocarcinoma. ${ }^{51}$ Furthermore, owing to the different expression of the corresponding receptors on various tumor cell surfaces, ${ }^{52}$ ketamine facilitates $a$ and $\beta$ adrenergic receptor activation, which may directly promote the apoptosis of tumor cells, but its role is still controversial.

\section{Tramadol}

Tramadol is a key analgesic drug with multiple analgesic mechanisms. Tramadol inhibits the reuptake of 5-HT and norepinephrine by binding to $\mu$ receptors and simultaneously activating the central monoaminergic system.

Gaspani et al ${ }^{53}$ reported that tramadol, which is equivalent to morphine, can effectively reduce immunosuppression caused by surgical stress and pain. In addition, tramadol inhibits the growth and metastasis of tumors. Notably, it exhibits higher activity than morphine on tumor biological effects such as proliferation, apoptosis, invasion and metastasis. Tramadol inhibits the proliferation and weakens the invasive ability of A549 cells by modulating the PTEN/PI3K/AKT signaling pathway and by inducing apoptosis. ${ }^{54}$ In addition, it can enhance the chemosensitivity of lung cancer A549 cells to cisplatin. ${ }^{55}$ These studies provide new evidence that treatment with tramadol may play an unappreciated role in tumor progression. We hope that exploring the mechanism through which tramadol exerts its tumor progression inhibitory effects will establish a role for determining prognosis and combination antineoplastic therapy.

\section{Midazolam}

Midazolam is a short-acting benzodiazepine sedative-hypnotic drug used for sedation and for the treatment of insomnia and epilepsy. Midazolam acts by binding to the benzodiazepine binding site of the gamma-aminobutyric acid type A receptor, thus mediating its primary clinical effects. In addition, midazolam binds to peripheral benzodiazepine receptors. Peripheral benzodiazepine receptors modulate a variety of cellular functions, including cell proliferation, oxidation and apoptosis.

Wang et $\mathrm{al}^{56}$ explored the effect of midazolam on the human lung cancer cell line A549 in vitro and in vivo. The findings indicated that midazolam inhibits the proliferation and migration of lung cancer cells in vitro and significantly downregulates the expression of Ki67 and cyclin $\mathrm{D}$ in xenograft mice. This may be partly mediated by peripheral benzodiazepine receptors.

A study by Makino et al reported that STAT3 plays an important role in the growth of lung cancer. ${ }^{57}$ The role of midazolam and miR-520d-5p in the induction of apoptosis in the NSCLC cell line A549 was explored. The findings indicated that midazolam upregulates the expression of miR-520d-5p in A549 cells and inhibits the growth of tumor cells by inhibiting STAT3 activity and inducing apoptosis.

These studies have explained to some extent the positive effect of general anesthesia combined with regional nerve block on the overall survival rate of lung cancer patients.

\section{Dexmedetomidine}

Dexmedetomidine is an $\alpha 2$ adrenergic receptor agonist with sedative, analgesic, anxiolytic, and sympatholytic effects. Dexmedetomidine exhibits different effects on the invasion and metastasis of different cancer cells through varying mechanisms. Several studies are currently exploring the effect of dexmedetomidine on the biological behavior of cancer cells.

\section{In vivo Studies on the Effect of Dexmedetomidine on Cancer}

Wang et al found that dexmedetomidine promotes the survival of cancer cells by modulating the $\alpha 2$-adrenoceptor signaling pathway in lung cancer and glioma cells. However, findings from in vivo studies showed that dexmedetomidine did not have significant effects on tumor growth. $^{56}$ 
Dexmedetomidine increases retention and metastatic growth of Lewis lung cancer cells in C57BL/6 mice. ${ }^{58}$ In addition, dexmedetomidine promotes the metastasis of postoperative lung cancer cells in mice by inducing monocyte bone marrow-derived inhibitory cell proliferation and increasing the production of vascular endothelial growth factor. ${ }^{59,60}$

\section{In vitro Studies on the Effect of Dexmedetomidine on Cancer}

Studies report that dexmedetomidine promotes hypoxiainduced lung cancer cell progression by regulating HIF- $1 \alpha$ signaling, which is associated with the $\alpha 2$ adrenergic receptor pathway. ${ }^{59}$

\section{Clinical Studies on the Effect of Dexmedetomidine on Cancer}

Several clinical studies report that dexmedetomidine affects the proliferation and metastasis of lung cancer cells. Dexmedetomidine induces the proliferation and inhibition of bone marrow-derived cells in postoperative patients with lung cancer. Notably, this cell group significantly promoted angiogenesis tendency score matching. Although intraoperative dexmedetomidine had no significant effect on the relapse-free survival rate of NSCLC patients, it showed an association with the overall survival rate. ${ }^{60}$ This illustrated to a certain extent the positive effect of dexmedetomidine on the overall survival rate of lung cancer patients.

\section{Muscle Relaxants}

The relationship between muscle relaxants and lung tumor metastasis has not been fully elucidated.

However, a previous study reported that cisatracurium inhibits the proliferation of A549 lung cancer cells when administered at a concentration greater than or equal to the clinical concentration. In addition, vecuronium bromide exerts an inhibitory effect when the concentration is higher than the intubation concentration. Moreover, cisatracurium and vecuronium bromide significantly inhibit the metastasis and invasion of lung cancer cells. ${ }^{61}$ More studies at the molecular, cellular, animal and clinical levels should be conducted to elucidate the underlying mechanism of the role of muscle relaxants in lung cancer metastasis.

\section{Inhalation Anesthetics}

Inhalation anesthetics mainly include isoflurane and sevoflurane. These drugs typically act on synapses or axonal membranes and inhibit nerve signal transduction by blocking ion transport. In addition, they inhibit the proliferation of immune cells, including NK cells and $\mathrm{T}$ lymphocytes. Inhalation anesthetics induce apoptosis in a dose- and time-dependent manner, reduce reconstruction of the immune system, and promote tumor proliferation, migration and recurrence. ${ }^{35}$

\section{Sevoflurane}

\section{In vivo Studies on the Effect of Sevoflurane on} Cancer

Pretreatment of Lewis lung cancer cells with sevoflurane inhibits lung metastasis in mice, which is attributed to the downregulation of MMP-2 and MMP-9 expression in cancer cells. ${ }^{62}$

Johnson et al conducted a study using a mouse breast tumor resection model and reported that lidocaine combined with sevoflurane reduces lung metastasis of breast cancer, probably through anti-inflammatory and antiangiogenic effects of the drugs. ${ }^{63}$

However, a previous study reported that sevoflurane (2 vol\%) promotes the proliferation of Lewis lung cancer cells in vitro but has no significant effect on cell proliferation in vivo. Kim et al conducted in vivo and in vitro experiments to explore the effect of sevoflurane on the proliferation of Lewis lung cancer cells (LLCs). The findings showed that sevoflurane promotes the proliferation of LLC cells in vitro but had no significant effect on the proliferation of LLC cells in vivo. These findings indicate that the effect of anesthetics on lung cancer cells in vivo may be different from the in vitro effects. ${ }^{64}$

\section{In vitro Studies on the Effects of Sevoflurane on Cancer}

Sevoflurane is metabolized by cytochrome P4502E1 in lung cancer to produce toxic products that reduce the expression of CD44 and CD54 and promote apoptosis of lung cancer cells. ${ }^{65}$ In addition, sevoflurane affects the invasive ability of non-small-cell lung cancer cells, ${ }^{66}$ and enhances the chemosensitivity of A549 cells to cisplatin. ${ }^{67,68}$ Sevoflurane downregulates the expression of MMP-2 and MMP-9, bundle protein and Ezi protein, which may be related to the inactivation of p38MAPK signaling pathways. ${ }^{66}$

In addition, placing a culture plate inoculated with an A549 single-cell suspension in a closed plexiglass box improves the invasiveness of lung cancer cells. ${ }^{69}$ Sevoflurane also inhibits HIF-1 $\alpha$-induced growth and metastasis of lung cancer cells. ${ }^{70}$ Moreover, $3 \%$ 
sevoflurane significantly promotes apoptosis of A549 lung cancer cells, mainly through induction of apoptosis by regulating the expression of miRNA. ${ }^{71}$

\section{Isoflurane, Desflurane, Halothane and Nitrous Oxide} Isoflurane promotes the proliferation, migration and invasion of lung cancer cells by activating the Akt-mTOR pathway. ${ }^{72}$

Studies report the formation of more lung tumors when desflurane-treated cancer cells are injected into mice. This effect can be attributed to the induction of EMT and cancer cell metastasis by modulation of the miR-34a/LOXL3 axis by desflurane. ${ }^{73}$

Shapiro et al used mouse models and reported that halothane promotes tumor progression and metastasis of lung cancer and induces liver metastasis. In addition, the findings showed that exposure to nitrous oxide for the induction of anesthesia was associated with increased metastasis of lung cancer and melanoma in surgically resected mice. ${ }^{74}$ The present results can aid anesthesiologists in the selection of appropriate inhalation anesthetics for patients with lung cancer.

\section{Nonsteroidal Anti-Inflammatory Drugs (NSAIDs)}

Previous studies report that cyclooxygenase (COX-2) expression is related to metastasis in multiple biological stages. The COX-2 gene is overexpressed in lung cancer, indicating that COX-2 is involved in the occurrence and development of lung cancer. ${ }^{75,76} \mathrm{COX}-2$ and prostaglandin E2 (PGE2) are major causes of cancer progression. ${ }^{76}$ As such, nonsteroidal anti-inflammatory drugs have potential anticancer effects. ${ }^{77}$ Inhibition of PGE2 production, secondary to the inhibition of COX-2, may play an important role in the mutation and proliferation of cancer cells. In addition, inhibition of COX has an anti-inflammatory effect, enhances the immune response and inhibits cell aggregation, which is an important mechanism for tumor metastasis. $^{78}$

Vogel et al explored the relationship between lung cancer risk and single nucleotide polymorphisms of genes involved in the inflammatory response. The findings showed that the use of NSAIDs changes the risk of lung cancer depending on genotype. ${ }^{79}$

The possible anticancer benefits of perioperative use of nonsteroidal anti-inflammatory drugs are only theoretical. Currently, no studies have explored the effect of nonsteroidal anti-inflammatory drugs on the survival rate or recurrence rate of cancer patients. However, as an analgesic with antitumor effects, the multimodal analgesic method using NSAIDs assisted with opioids during the perioperative period may be a new option for cancer patients to improve their clinical outcomes.

\section{Local Anesthetics}

Local anesthetics can temporarily, completely or reversibly block sensory nerve impulses and the conduction of signals, thus reducing local pain and sensation. The main mechanism of action of local anesthetics is binding to voltage-gated sodium channels, thus blocking $\mathrm{Na}^{+}$influx and reducing the excitability of nerve cells. These effects ultimately block nerve impulses and signal conduction. Previous studies report that local anesthetics can inhibit tumor growth.

\section{In vitro Study}

Local anesthetics, mainly amide local anesthetics, have been widely studied. ${ }^{80}$ Lidocaine exhibits antigrowth and antimetastatic effects on lung cancer cells by upregulating miR-539 and blocking EGFR signaling via directly binding to EGFR ${ }^{81}$ Lidocaine and ropivacaine attenuate TNF- $\alpha$-induced Src activation in pulmonary endothelial cells to maintain endothelial barrier function $^{82}$ and reduce cancer cell migration through phosphorylation of intercellular adhesion molecule- $1 .{ }^{83}$ Therapeutic concentrations of lidocaine show significant inhibition of Src phosphorylation and ICAM-1 expression in human lung cancer cells in vitro. ${ }^{84} \mathrm{~A}$ study by Pigeler reported that inhibition of $\mathrm{TNF} \alpha$-induced $\mathrm{Src}$ activity and reduction of activated Src through phosphorylation can inhibit the growth and metastasis of lung cancer cells. ${ }^{85}$

Lidocaine, ropivacaine and bupivacaine inhibit cell proliferation and differentiation, exert cytotoxicity to mesenchymal stem cells in vitro, and play an important role in tumor growth, metastasis and development of cancer cells. ${ }^{86}$ Studies on procaine report that low-dose procaine inhibits the proliferation of lung cancer cells; however, the effect is not observed at high doses of procaine. ${ }^{87}$

\section{In vivo Studies}

A study was conducted on the 4T1 mouse breast cancer model and reported that lidocaine and propofol reduced 
lung metastasis on the 14 th day after operation. ${ }^{16}$ This is consistent with the results of another study. ${ }^{88}$ Lidocaine, combined with sevoflurane anesthesia, may reduce lung metastasis through anti-inflammatory and antiangiogenic effects in a $4 \mathrm{~T} 1$ breast cancer mouse model.

Although several experimental studies report that perioperative use of regional and local anesthetics has potential beneficial effects, the exact role and effects of local anesthetics in cancer surgery are not clear owing to the lack of clinical data from randomized controlled trials. Further studies should explore whether intravenous infusion of lidocaine improves the prognosis of cancer patients after surgery. However, it may also be an ideal adjuvant for cancer treatment.

\section{Effects of Different Anesthetic Methods on Tumor Metastasis and Recurrence}

Different anesthesia methods may affect the microenvironment of cell growth. ${ }^{89}$ Various retrospective studies have explored the association between anesthetic regimens and tumor recurrence/metastasis and/or patient survival. The findings indicate that anesthesia regimens play important roles in tumor metastasis and/or recurrence after surgery. ${ }^{90}$ The studies are summarized in Table 2.

$\mathrm{Xu}$ et al reported that different anesthesia methods affect the serum environment, thus affecting the biological behavior of tumor cells and potentially leading to metastasis of tumor cells. ${ }^{91}$ Different anesthesia methods, including epidural anesthesia, intravenous anesthesia, inhalation anesthesia, combined intravenousinhalation anesthesia, and intercostal nerve block, have different effects on the growth and metastasis of cancer cells. $^{92,93}$

\section{Total Intravenous Anesthesia}

Several clinical studies report that total intravenous anesthesia (TIVA) is correlated with a longer survival rate than inhaled anesthetics in cancer surgery. ${ }^{31,94-96}$ In contrast, retrospective analysis of lung cancer patients indicated that TIVA did not significantly improve patient prognosis compared with inhalation anesthesia. ${ }^{97,98}$

\section{Regional Anesthesia and Spinal Canal Anesthesia}

A retrospective clinical study reported that regional anesthesia reduces postoperative tumor recurrence. ${ }^{99}$ Ketamine and propofol anesthesia induced more lung tumor metastases in Fischer 344 rats administered MADB106 tumor cells through the tail vein after exploratory laparotomy than intraspinal anesthesia. This finding indicates that intraspinal anesthesia is more effective than general anesthesia in protecting immune surveillance function. ${ }^{5,100}$ Another study reported that although paravertebral block did not reduce tumor recurrence, it was correlated with a higher overall survival after lung cancer surgery. ${ }^{101}$

Moreover, Jingbo et al reported that a combination of epidural and general anesthesia is more effective in preventing specific short-term adverse events, improving long-term survival, maintaining hemodynamic stability, and inhibiting surgical stress-mediated inflammatory responses compared to administration of general anesthesia alone in patients with early-stage NSCLC after tumor resection. ${ }^{102}$

$\mathrm{Xu}$ et $\mathrm{al}^{103}$ recommended a combination of generalepidural anesthesia (CGEA) for radical resection of NSCLC patients. The findings showed that postoperative CD4+ and $\mathrm{CD} 4+/ \mathrm{CD} 8+$ values after administration of the combined anesthesia therapy were higher than those of patients administered TIVA. In addition, the combined anesthesia therapy exhibited less interference on cellular immune function than the use of TIVA.

Another study reported similar findings, ${ }^{104}$ wherein patients undergoing radical lung cancer surgery who received TIVA combined with epidural anesthesia and epidural analgesia had less interference with the immune system and a faster recovery. Perioperative immune system function is highly correlated with the risk of postoperative infection and disease progression in cancer patients. ${ }^{105,106}$ Therefore, minimizing factors that lead to immunosuppression is important.

Sen et al ${ }^{107}$ explored the effects of paravertebral nerve block combined with propofol intravenous anesthesia and sevoflurane inhalation anesthesia on serum VEGF and transforming growth factor- $\beta$ (TGF- $\beta$ ) in patients undergoing radical resection of lung cancer. The findings showed that paraspinal nerve block improves the effect of postoperative analgesia and reduces the levels of tumor 
Table 2 Effects of Different Anesthetic Methods on Tumor Metastasis and Recurrence

\begin{tabular}{|c|c|c|c|c|c|}
\hline Title & $\begin{array}{l}\text { Study } \\
\text { Authors }\end{array}$ & Year & Type & $\begin{array}{l}\text { Techniques } \\
\text { Compared }\end{array}$ & Significant Results \\
\hline $\begin{array}{l}\text { Effects of anaesthesia on proliferation, invasion and apoptosis of LoVo } \\
\text { colon cancer cells in vitro. }{ }^{91}\end{array}$ & $\begin{array}{l}\mathrm{Xu} \mathrm{YJ} \\
\text { et al }\end{array}$ & 2016 & $\begin{array}{l}\text { In vitro } \\
\text { study }\end{array}$ & $\begin{array}{l}\text { GA+ epidural }(n \\
=20) ; \text { INHA } \\
\text { +opioid }(n=20)\end{array}$ & $\begin{array}{l}\text { Inhibited the proliferation and invasion of LoVo cells and induced } \\
\text { apoptosis in GA+ epidural group }\end{array}$ \\
\hline $\begin{array}{l}\text { Effects of neuraxial block and general anesthesia on tumor metastasis } \\
\text { in rats } 100\end{array}$ & $\begin{array}{l}\text { Zheng } \\
\text { Wei et al }\end{array}$ & 2008 & $\begin{array}{l}\text { In vivo } \\
\text { study }\end{array}$ & $\begin{array}{l}\text { Ketamine, } \\
\text { propofol, } \\
\text { neuraxial block. }\end{array}$ & $\begin{array}{l}\text { Compared with those in group neuraxial block, CD3(+), CD4(+), CD8 } \\
(+), \text { CD I6 la }(+) \text { lymphocytes the activity of circulating NK cells were } \\
\text { significantly reduced in ketamine and Propofol; the lung metastases of } \\
\text { MADBI06 increased significantly in groups } K \text { and } P(P<0.05 \text { or } 0.01) \text {. }\end{array}$ \\
\hline $\begin{array}{l}\text { Long-term Survival for Patients Undergoing Volatile versus IV } \\
\text { Anesthesia for Cancer Surgery:A Retrospective Analysis. }{ }^{94}\end{array}$ & $\begin{array}{l}\text { Wigmore } \\
\text { J et al }\end{array}$ & 2016 & $\begin{array}{l}\text { Clinical } \\
\text { research }\end{array}$ & $\begin{array}{l}\text { INHA }(\mathrm{n}=3316) \\
\text { TIVA }(\mathrm{n}=3714)\end{array}$ & $\begin{array}{l}\text { INHA was associated with a hazard ratio of } \mathrm{I} .59 \text { ( } 1.30 \text { to } 1.95) \text { for death } \\
\text { on univariate analysis and } \mathrm{I} .46 \text { ( } 1.29 \text { to } 1.66) \text { after multivariable analysis } \\
\text { in TIVA }\end{array}$ \\
\hline $\begin{array}{l}\text { Impact of anesthetic agents on overall and recurrence-free survival in } \\
\text { patients undergoing esophageal cancer surgery:A retrospective } \\
\text { observational study }\end{array}$ & Jun I.J et al & 2017 & $\begin{array}{l}\text { Clinical } \\
\text { research }\end{array}$ & $\begin{array}{l}\text { INHA }(n=191) \\
\text { TIVA }(n=731)\end{array}$ & $\begin{array}{l}\text { INHA was independently associated with worse OR (HR I.58); and RFS } \\
\text { (HR I.42); after multivariable analysis adjustment. in PSM cohorts, INHA } \\
\text { was associated with worse OR (HR I.45) and RFS (HR I.44). }\end{array}$ \\
\hline $\begin{array}{l}\text { Long-Term Oncologic Outcomes for Patients Undergoing Volatile } \\
\text { Versus Intravenous Anesthesia for Non-Small Cell Lung Cancer } \\
\text { Surgery: A Retrospective Propensity Matching Analysis. }{ }^{97}\end{array}$ & Oh et al & 2018 & $\begin{array}{l}\text { Clinical } \\
\text { research }\end{array}$ & $\begin{array}{l}\text { INHA }(\mathrm{n}=194) \\
\text { TIVA }(\mathrm{n}=749)\end{array}$ & $\begin{array}{l}\text { No difference in }(H R) \text { for recurrence between the TIVA and INHA } \\
\text { groups }(P=0.233) \text {; No difference in }(H R) \text { for death }(P=0.55 \mathrm{I}) \text {. }\end{array}$ \\
\hline $\begin{array}{l}\text { A comparison of regional and general anesthesia effects on } 5 \text { year } \\
\text { survival and cancer recurrence after transurethral resection of the } \\
\text { bladder tumor:a retrospective analysis. }{ }^{99}\end{array}$ & $\begin{array}{l}\text { Jang } D \\
\text { et al }\end{array}$ & 2016 & $\begin{array}{l}\text { Clinical } \\
\text { research }\end{array}$ & $\begin{array}{l}\text { GA }(n=24) \\
\text { regional(spinal or } \\
\text { epidural) }(n=137)\end{array}$ & $\begin{array}{l}\text { Five-year survival was } 87.5 \% \text { for } G A \text { and } 96.3 \% \text { for regional }(P=0.099) \text {. } \\
\text { Regional anesthesia showed higher } 5 \text {-year survival (coefficient }=-0.167 \text {, } \\
\text { more than GA through the partial correlation analysis. }\end{array}$ \\
\hline $\begin{array}{l}\text { Paravertebral block does not reduce cancer recurrence, but is related } \\
\text { to higher overall survival in lung cancer surger: a retrospective cohort } \\
\text { study }{ }^{101}\end{array}$ & $\begin{array}{l}\text { Lee EK } \\
\text { et al }\end{array}$ & 2017 & $\begin{array}{l}\text { Clinical } \\
\text { research }\end{array}$ & $\begin{array}{l}\text { PCA }(n=574) \\
\text { TEA }(n=619) \\
\text { PVB }(n=536)\end{array}$ & $\begin{array}{l}\text { Analgesic method was associated with OS }(P=0.0015) \text {; HR against TEA } \\
{[95 \% \text { confidence intervals]: PCA } 0.58 \text { PVB0.60. After PSM, PVB showed }} \\
\text { higher OR. No significant in RFS }\end{array}$ \\
\hline $\begin{array}{l}\text { Combined anesthesia shows better curative effect and less } \\
\text { perioperative neuroendocrine disorder than general anesthesia in early } \\
\text { stage NSCLC patients }{ }^{102}\end{array}$ & Pi et al & 2019 & $\begin{array}{l}\text { Clinical } \\
\text { research }\end{array}$ & $\begin{array}{l}\text { GA }(n=76) \\
\text { GA+ epidural }(n \\
=74)\end{array}$ & $\begin{array}{l}\text { Lower specific adverse events and improved OR, PFS were in GA+ } \\
\text { epidural group; Lower MAP and levels of IL-I, IL- } 8 \text {, hs-CRP, TNF- } \alpha \text {, MDA } \\
\text { in GA group }\end{array}$ \\
\hline $\begin{array}{l}\text { Effects of combined general-epidural anesthesia and total intravenous } \\
\text { anesthesia on cellular immunity and prognosis in patients with non- } \\
\text { small cell lung cancer: A comparative study. }{ }^{103}\end{array}$ & $\begin{array}{l}\text { Xu Q } \\
\text { et al }\end{array}$ & 2017 & $\begin{array}{l}\text { Clinical } \\
\text { research }\end{array}$ & $\begin{array}{l}\text { GA+ epidural }(n \\
=60) \\
\text { TIVA }(n=60)\end{array}$ & $\begin{array}{l}\text { At } 24 \text { and } 48 \text { h after surgery, higher } C D 3+, C D 4+, C D 4+/ C D 8+\text { and } \\
C D 56+\text { in group } G A+\text { epidural, after } 72 h \text { surgery, higherCD3+, CD4+, } \\
C D 4+/ C D 8+\text { in group GA+ epidural. }\end{array}$ \\
\hline
\end{tabular}




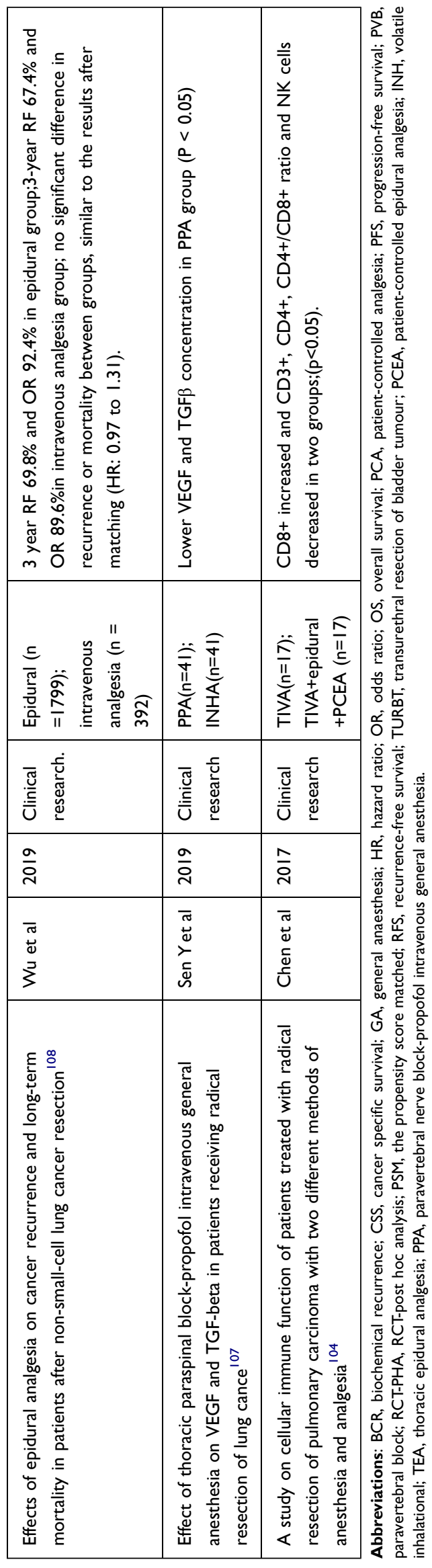

angiogenesis-related factors in serum. These findings indicate that regional nerve block improves postoperative stress and immunosuppression, ultimately affecting the prognosis of patients.

A large-scale retrospective study using propensity scores to evaluate the effect of epidural analgesia on tumor outcome after lung cancer surgery reported that epidural analgesia was not correlated with improvement in recurrence-free survival or overall survival in patients with non-small-cell lung cancer. ${ }^{108}$

Current research has shown that combined anesthesia is an ideal method that appears to be superior to general anesthesia alone in enhancing the analgesic effect, reducing the intraoperative stress response, decreasing immune suppression, and preventing tumor metastasis in patients with NSCLC. This suggests that combined anesthesia may have certain value in the treatment of lung cancer.

Table 3 provides a summary of both Anesthesia or Anesthesia on Metastasis of Lung Cancer.

\section{Conclusion and Prospect}

In summary, several factors affect the metastasis and recurrence of lung tumors, and studies report that anesthetic drugs affect cancer metastasis. The rational use of anesthetic drugs and the selection of anesthetic methods can enhance antitumor effects and reduce the risk of tumor recurrence and metastasis. Our previous in vitro studies also indicated that intravenous anesthetic agents, including propofol, sufentanil and rocuronium, inhibited the proliferation of A549 lung cancer cells. The inhibitory effect of the combination of the three drugs at clinical concentrations on cell proliferation was stronger than each one separately (unpublished data). Furthermore, our in vivo experiments demonstrated that three-drug combination treatment could also inhibit tumor growth in xenograft models (unpublished data). Our future studies should focus on investigating the interaction between anesthetics and the mechanism of the development process of lung cancer. Exploring the biological relationship between anesthetics and lung cancer, providing information on the inhibitory effect of certain anesthetic drugs on tumor micrometastasis in clinical anesthesia, and developing individualized and effective anesthetic regimens may help reduce the incidence of tumor micrometastasis and improve the postoperative survival rate of cancer patients. 
Table 3 Effect of Anesthesia or Anesthesia on Metastasis of Lung Cancer

\begin{tabular}{|c|c|c|c|c|}
\hline Anesthetic Factors & In vivo Study & In vitro Study & In Clinical Studies & $\begin{array}{l}\text { Predominant } \\
\text { Effects }\end{array}$ \\
\hline \multicolumn{5}{|l|}{ Intravenous drug } \\
\hline $\begin{array}{l}\text { Propofol } \\
\text { Etomidate } \\
\text { Opioids }\end{array}$ & $\begin{array}{l}\text { Inhibition }^{16,18,19} \\
\text { Activation }^{38,40}\end{array}$ & $\begin{array}{c}\text { Inhibition }^{17,20-26} \\
\text { Inhibition }^{33} \\
\text { Dose-dependent, }{ }^{43} \\
\text { depressed NK activity }\end{array}$ & $\begin{array}{c}\text { Inhibition }^{32} \\
\text { Inhibition }^{34} \\
\text { Increase recurrence } \\
\text { 47,49 }\end{array}$ & $\begin{array}{c}\text { Beneficial } \\
\text { Beneficial } \\
\text { Inconclusive }\end{array}$ \\
\hline Methylnaltrexone & Inhibition $^{40,42}$ & Inhibition ${ }^{40,41}$ & & Beneficial \\
\hline $\begin{array}{l}\text { Ketamine } \\
\text { Tramadol } \\
\text { Midazolam }\end{array}$ & $\begin{array}{l}\text { Activation }^{5,12} \\
\text { Inhibition }^{54} \\
\text { Inhibition }^{56}\end{array}$ & Inhibition $^{56,57}$ & Inhibition ${ }^{51,52}$ & $\begin{array}{l}\text { Inconclusive } \\
\text { Beneficial } \\
\text { Beneficial }\end{array}$ \\
\hline Dexmedetomidine & Activation $^{56}$ & Inhibition $^{59}$ & Activation $^{60}$ & Inconclusive \\
\hline NSAIDs & Inhibition $^{79}$ & & & Beneficial \\
\hline Muscle relaxant cisatracurium vecuronium & & Inhibition $^{61}$ & & Beneficial \\
\hline \multicolumn{5}{|l|}{ Volatile agents } \\
\hline $\begin{array}{l}\text { Sevoflurane } \\
\text { Isoflurane } \\
\text { Desflurane } \\
\text { Halothane }\end{array}$ & $\begin{array}{l}\text { Inhibition }^{62,63} \\
\text { Activation }^{73} \\
\text { Activation }^{74}\end{array}$ & $\begin{array}{l}\text { Activation 64, inhibition } \\
\text { increase sensitivity to } \\
\text { chemotherapy }^{67,68} \\
\text { Inhibition } \\
\text { activation }^{72}\end{array}$ & & $\begin{array}{l}\text { Inconclusive } \\
\text { Inconclusive } \\
\text { Harmful } \\
\text { Harmful }\end{array}$ \\
\hline \multicolumn{5}{|l|}{ Local anesthetics } \\
\hline $\begin{array}{l}\text { Lidocaine } \\
\text { Ropivacaine } \\
\text { Bupivacaine } \\
\text { procaine }\end{array}$ & Inhibition ${ }^{16,88}$ & Inhibition $^{81-87}$ & & Beneficial \\
\hline \multicolumn{5}{|l|}{ Anesthetic techniques } \\
\hline TIVA VS inhaled anesthetics & & & $\begin{array}{l}\text { Longer survival rate with TIVA } \\
\text { Not improve prognosis } \\
31,97,98\end{array}$ & Inconclusive \\
\hline PVB VS PCA VS TEA & & & Longer overall survival with $\mathrm{PVB}^{101}$ & Benefit of PVB \\
\hline $\begin{array}{l}\text { Epidural combined general anesthesia } \\
\text { VS general anesthesia }\end{array}$ & & & $\begin{array}{l}\text { Improving long-term survival in } \\
\text { Combined anesthesia }{ }^{10}\end{array}$ & $\begin{array}{l}\text { Benefit of } \\
\text { combined } \\
\text { anesthesia }\end{array}$ \\
\hline CGEA VS TIVA & & & $\begin{array}{l}\text { Less interference with the immune } \\
\text { system }{ }^{103,104}\end{array}$ & Benefit of CGEA \\
\hline Epidural analgesia & & & $\begin{array}{l}\text { No difference in recurrence-free } \\
\text { survival or overall survival }\end{array}$ & Inconclusive \\
\hline
\end{tabular}

Abbreviations: NSAIDs, non-steroidal anti-inflammatory drugs; TIVA, total intravenous anesthesia; PVB, paravertebral block; TEA, thoracic epidural analgesia; PCA, patient-controlled analgesia; CGEA, combination of general-epidural anesthesia. 


\section{Ethics Approval}

None of the authors are involved in any research conducted by humans or animals in this article.

\section{Consent to Participate}

Informed consent was obtained from all participants

\section{Author Contributions}

All authors made a significant contribution to the work reported, whether that is in the conception, study design, execution, acquisition of data, analysis and interpretation, or in all these areas; took part in drafting, revising or critically reviewing the article; gave final approval of the version to be published; have agreed on the journal to which the article has been submitted; and agree to be accountable for all aspects of the work.

\section{Disclosure}

The authors report no conflicts of interest in this work.

\section{References}

1. Siegel RL, Miller KD, Fuchs HE, Jemal A. Cancer statistics, 2021. CA Cancer J Clin. 2021;71(1):7-33. doi:10.3322/ caac. 21654

2. Wan L, Pantel K, Kang Y. Tumor metastasis: moving new biological insights into the clinic. Nat Med. 2013;19(11):1450-1464. doi: $10.1038 / \mathrm{nm} .3391$

3. Sung H, Ferlay J, Siegel RL, et al. Global cancer statistics 2020: GLOBOCAN estimates of incidence and mortality worldwide for 36 cancers in 185 countries. CA Cancer J Clin. 2021;71(3):209249. doi: $10.3322 /$ caac. 21660

4. DeSantis CE, Lin CC, Mariotto AB, et al. Cancer treatment and survivorship statistics, 2014. CA Cancer J Clin. 2014;64(4):252271. doi:10.3322/caac. 21235

5. Miller KD, Nogueira L, Mariotto AB, et al. Cancer treatment and survivorship statistics, 2019. CA Cancer J Clin. 2019;69(5):363385. doi:10.3322/caac. 21565

6. Park Y, Kitahara T, Takagi R, Kato R. Does surgery for breast cancer induce angiogenesis and thus promote metastasis? Oncology. 2011;81(3-4):199-205. doi:10.1159/000333455

7. Harting MT, Blakely ML. Management of osteosarcoma pulmonary metastases. Semin Pediatr Surg. 2006;15(1):25-29. doi:10.1053/j.sempedsurg.2005.11.005

8. Leong SP, Cady B, Jablons DM, et al. Clinical patterns of metastasis. Cancer Metastasis Rev. 2006;25(2):221-232. doi:10.1007/ s10555-006-8502-8

9. Inada T, Kubo K, Kambara T, Shingu K. Propofol inhibits cyclooxygenase activity in human monocytic THP-1 cells. Can $J$ Anaesthes. 2009;56(3):222-229. doi:10.1007/s12630-008-9035-0

10. Woo JH, Baik HJ, Kim CH, et al. Effect of propofol and desflurane on immune cell populations in breast cancer patients: a randomized trial. J Korean Med Sci. 2015;30(10):1503-1508. doi:10.3346/jkms.2015.30.10.1503

11. Loop T, Dovi-Akue D, Frick M, et al. Volatile anesthetics induce caspase-dependent, mitochondria-mediated apoptosis in human T lymphocytes in vitro. Anesthesiology. 2005;102(6):1147-1157. doi:10.1097/00000542-200506000-00014
12. Melamed R, Bar-Yosef S, Shakhar G, Shakhar K, Ben-Eliyahu S. Suppression of natural killer cell activity and promotion of tumor metastasis by ketamine, thiopental, and halothane, but not by propofol: mediating mechanisms and prophylactic measures. Anesth Analg. 2003;97(5):1331-1339. doi:10.1213/01.ANE.00 00082995.44040 .07

13. Lukoseviciene V, Tikuisis R, Dulskas A, Miliauskas P, Ostapenko V. Surgery for triple-negative breast cancer- does the type of anaesthesia have an influence on oxidative stress, inflammation, molecular regulators, and outcomes of disease? J BUON. 2018;23 (2):290-295.

14. Wall T, Sherwin A, Ma D, Buggy DJ. Influence of perioperative anaesthetic and analgesic interventions on oncological outcomes: a narrative review. Br J Anaesth. 2019;123(2):135-150. doi:10. 1016/j.bja.2019.04.062

15. Wang J, Cheng CS, Lu Y, et al. Novel findings of anti-cancer property of propofol. Anticancer Agents Med Chem. 2018;18 (2):156-165. doi:10.2174/1871520617666170912120327

16. Freeman J, Crowley PD, Foley AG, et al. Effect of perioperative lidocaine, propofol and steroids on pulmonary metastasis in a murine model of breast cancer surgery. Cancers (Basel). 2019;11(5):613. doi:10.3390/cancers 11050613

17. Li R, Huang Y, Lin J. Distinct effects of general anesthetics on lung metastasis mediated by IL-6/JAK/STAT3 pathway in mouse models. Nat Commun. 2020;11(1):642. doi:10.1038/s41467-01914065-6

18. Wang W, Lin C, Zhang Y, Chen Y, Guo P. [Effects of propofol on pulmonary metastasis of intravenously injected MADB106 tumor cells and expression of E-cadherin and $\beta$-catenin in rats]. Nan Fang Yi Ke Da Xue Xue Bao. 2015;35(6):852-856. Chinese.

19. Zhang Y, Lin C, Wang W, Chen Y. [Effects of propofol on pulmonary metastasis of intravenous injected tumor cells and expressions of MTA1 and Wnt1 in rats]. Nan Fang Yi Ke Da Xие Xue Bao. 2014;34(7):1011-1015. Chinese.

20. Ye HJ, Bai JJ, Guo PP, Wang W, Lin CS. [Propofol suppresses invasion of human lung cancer A549 cells by down-regulating aquaporin-3 and matrix metalloproteinase-9]. Nan Fang Yi Ke Da Хие Xие Bao. 2016;36(9):1286-1290. Chinese.

21. Cui WY, Liu Y, Zhu YQ, Song T, Wang QS. Propofol induces endoplasmic reticulum (ER) stress and apoptosis in lung cancer cell H460. Tumour Biol. 2014;35(6):5213-5217. doi:10.1007/ s13277-014-1677-7

22. Wu KC, Yang ST, Hsia TC, et al. Suppression of cell invasion and migration by propofol are involved in down-regulating matrix metalloproteinase-2 and p38 MAPK signaling in A549 human lung adenocarcinoma epithelial cells. Anticancer Res. 2012;32 (11):4833-4842.

23. Yang N, Liang Y, Yang P, Ji F. Propofol suppresses LPS-induced nuclear accumulation of HIF-1 $\alpha$ and tumor aggressiveness in nonsmall cell lung cancer. Oncol Rep. 2017;37(5):2611-2619. doi:10.3892/or.2017.5514

24. Liu WZ, Liu N. Propofol inhibits lung cancer A549 cell growth and epithelial-mesenchymal transition process by upregulation of microRNA-1284. Oncol Res. 2018;27(1):1-8. doi:10.3727/ 096504018X15172738893959

25. Sun H, Gao D. Propofol suppresses growth, migration and invasion of A549 cells by down-regulation of miR-372. BMC Cancer. 2018;18(1):1252. doi:10.1186/s12885-018-5175-y

26. Xing SG, Zhang KJ, Qu JH, Ren YD, Luan Q. Propofol induces apoptosis of non-small cell lung cancer cells via ERK1/2-dependent upregulation of PUMA. Eur Rev Med Pharmacol Sci. 2018;22(13):4341-4349. doi:10.26355/eurrev_201807_15431

27. Jing $\mathrm{XG}$, Chen TF, Huang $\mathrm{C}$, et al. MiR-15a expression analysis in non-small cell lung cancer A549 cells under local hypoxia microenvironment. Eur Rev Med Pharmacol Sci. 2017;21 (9):2069-2074. 
28. Yang SL, Ren QG, Wen L, Hu JL. Clinicopathological and prognostic significance of hypoxia-inducible factor-1 alpha in lung cancer: a systematic review with meta-analysis. J Huazhong Univ Sci Technolog Med Sci. 2016;36(3):321-327. doi:10.1007/ s11596-016-1586-7

29. Ren W, Mi D, Yang K, et al. The expression of hypoxia-inducible factor- $1 \alpha$ and its clinical significance in lung cancer: a systematic review and meta-analysis. Swiss Med Wkly. 2013;143:w13855. doi:10.4414/smw.2013.13855

30. Yang N, Liang Y, Yang P, Yang T, Jiang L. Propofol inhibits lung cancer cell viability and induces cell apoptosis by upregulating microRNA-486 expression. Braz J Med Biol Res. 2017;50(1): e5794. doi:10.1590/1414-431x20165794

31. Jun IJ, Jo JY, Kim JI, et al. Impact of anesthetic agents on overall and recurrence-free survival in patients undergoing esophageal cancer surgery: a retrospective observational study. Sci Rep. 2017;7(1):14020. doi:10.1038/s41598-017-14147-9

32. Ren XF, Li WZ, Meng FY, Lin CF. Differential effects of propofol and isoflurane on the activation of T-helper cells in lung cancer patients. Anaesthesia. 2010;65(5):478-482. doi:10.1111/ j.1365-2044.2010.06304.x

33. Chu $\mathrm{CN}, \mathrm{Wu} \mathrm{KC}$, Chung WS, et al. Etomidate suppresses invasion and migration of human A549 lung adenocarcinoma cells. Anticancer Res. 2019;39(1):215-223. doi:10.21873/anticanres. 13100

34. Liu J, Dong W, Wang T, et al. Effects of etomidate and propofol on immune function in patients with lung adenocarcinoma. Am J Transl Res. 2016;8(12):5748-5755.

35. Kurosawa S. Anesthesia in patients with cancer disorders. Curr Opin Anaesthesiol. 2012;25(3):376-384. doi:10.1097/ACO.0b0 $13 \mathrm{e} 328352 \mathrm{~b} 4 \mathrm{a} 8$

36. Tegeder I, Geisslinger G. Opioids as modulators of cell death and survival-unraveling mechanisms and revealing new indications. Pharmacol Rev. 2004;56(3):351-369. doi:10.1124/pr.56.3.2

37. Zylla D, Kuskowski MA, Gupta K, Gupta P. Association of opioid requirement and cancer pain with survival in advanced non-small cell lung cancer. Br J Anaesth. 2014;113(Suppl 1): i109-i116. doi:10.1093/bja/aeu351

38. Fujioka N, Nguyen J, Chen C, et al. Morphine-induced epidermal growth factor pathway activation in non-small cell lung cancer. Anesth Analg. 2011;113(6):1353-1364. doi:10.1213/ANE.0b01 $3 \mathrm{e} 318232 \mathrm{~b} 35 \mathrm{a}$

39. Boehncke S, Hardt K, Schadendorf D, Henschler R, Boehncke WH, Duthey B. Endogenous $\mu$-opioid peptides modulate immune response towards malignant melanoma. Exp Dermatol. 2011;20 (1):24-28. doi:10.1111/j.1600-0625.2010.01158.x

40. Mathew B, Lennon FE, Siegler J, et al. The novel role of the mu opioid receptor in lung cancer progression: a laboratory investigation. Anesth Analg. 2011;112(3):558-567. doi:10.1213/ANE.0b 013e31820568af

41. Singleton PA, Lingen MW, Fekete MJ, Garcia JG, Moss J. Methylnaltrexone inhibits opiate and VEGF-induced angiogenesis: role of receptor transactivation. Microvasc Res. 2006;72(12):3-11. doi:10.1016/j.mvr.2006.04.004

42. Singleton PA, Moss J. Effect of perioperative opioids on cancer recurrence: a hypothesis. Future Oncol. 2010;6(8):1237-1242. doi:10.2217/fon.10.99

43. Shavit Y, Ben-Eliyahu S, Zeidel A, Beilin B. Effects of fentanyl on natural killer cell activity and on resistance to tumor metastasis in rats. Dose and timing study. Neuroimmunomodulation. 2004;11 (4):255-260. doi:10.1159/000078444

44. Forget P, Collet V, Lavand'homme P, De Kock M. Does analgesia and condition influence immunity after surgery? Effects of fentanyl, ketamine and clonidine on natural killer activity at different ages. Eur J Anaesthesiol. 2010;27(3):233-240. doi:10.1097/ EJA.0b013e32832d540e
45. Cata JP, Keerty V, Keerty D, et al. A retrospective analysis of the effect of intraoperative opioid dose on cancer recurrence after non-small cell lung cancer resection. Cancer Med. 2014;3 (4):900-908. doi:10.1002/cam4.236

46. Zylla D, Gourley BL, Vang D, et al. Opioid requirement, opioid receptor expression, and clinical outcomes in patients with advanced prostate cancer. Cancer. 2013;119(23):4103-4110. doi: $10.1002 /$ cncr. 28345

47. Maher DP, Wong W, White PF, et al. Association of increased postoperative opioid administration with non-small-cell lung cancer recurrence: a retrospective analysis. Br J Anaesth. 2014;113 (Suppl 1):i88-94. doi:10.1093/bja/aeu192

48. Wang K, Qu X, Wang Y, Shen H, Liu Q, Du J. Effect of mu agonists on long-term survival and recurrence in nonsmall cell lung cancer patients. Medicine. 2015;94(33):e1333. doi:10.1097/ MD.0000000000001333

49. Oh TK, Jeon JH, Lee JM, et al. Investigation of opioid use and long-term oncologic outcomes for non-small cell lung cancer patients treated with surgery. PLoS One. 2017;12(7):e0181672. doi:10.1371/journal.pone.0181672

50. Ohta N, Ohashi Y, Fujino Y. Ketamine inhibits maturation of bone marrow-derived dendritic cells and priming of the Th1type immune response. Anesth Analg. 2009;109(3):793-800. doi:10.1213/ane.0b013e3181 adc384

51. Connolly JG, Tan KS, Mastrogiacomo B, et al. Intraoperative opioid exposure, tumour genomic alterations, and survival differences in people with lung adenocarcinoma. $B r J$ Anaesth. 2021;127(1):75-84. doi:10.1016/j.bja.2021.03.030

52. Song JY, Lee SW, Hong JP, Chang SE, Choe H, Choi J. Epidermal growth factor competes with EGF receptor inhibitors to induce cell death in EGFR-overexpressing tumor cells. Cancer Lett. 2009;283(2):135-142. doi:10.1016/j.canlet.2009. 03.034

53. Gaspani L, Bianchi M, Limiroli E, Panerai AE, Sacerdote P. The analgesic drug tramadol prevents the effect of surgery on natural killer cell activity and metastatic colonization in rats. $J$ Neuroimmunol. 2002;129(1-2):18-24. doi:10.1016/S0165-5728 (02)00165-0

54. Xia M, Tong JH, Ji NN, Duan ML, Tan YH, Xu JG. Tramadol regulates proliferation, migration and invasion via PTEN/PI3K/ AKT signaling in lung adenocarcinoma cells. Eur Rev Med Pharmacol Sci. 2016;20(12):2573-2580.

55. Ming X, Jianhua T, Yipeng G, et al. Effects of tramadol combined with cisplatin on invasion and migration of human lung adenocarcinoma cell line A549. J Clin Anesthesiol. 2015;31(4):391394.

56. Wang C, Datoo T, Zhao H, et al. Midazolam and dexmedetomidine affect neuroglioma and lung carcinoma cell biology in vitro and in vivo. Anesthesiology. 2018;129(5):1000-1014. doi:10.10 97/ALN.0000000000002401

57. Makin JH, Bae E, Bae E, et al. Repression of Smad3 by Stat 3 and c-Ski/SnoN induces gefitinib resistance in lung adenocarcinoma. Biochem Biophys Res Commun. 2017;484(2):269-277. doi:10.10 16/j.bbrc.2017.01.093

58. Lavon H, Matzner P, Benbenishty A, et al. Dexmedetomidine promotes metastasis in rodent models of breast, lung, and colon cancers. Br J Anaesth. 2018;120(1):188-196. doi:10.1016/j. bja.2017.11.004

59. Su X, Fan Y, Yang L, et al. Dexmedetomidine expands monocytic myeloid-derived suppressor cells and promotes tumour metastasis after lung cancer surgery. J Transl Med. 2018;16(1):347. doi:10.1186/s12967-018-1727-9

60. Cata JP, Singh V, Lee BM, et al. Intraoperative use of dexmedetomidine is associated with decreased overall survival after lung cancer surgery. J Anaesthesiol Clin Pharmacol. 2017;33(3):317323. doi:10.4103/joacp.JOACP_299_16 
61. IddrisuBabaYabasin (Abasson). Effects of Cis Atracurium and Vecuronium on Human Lung Cancer and Hepatocellular Carcinoma Cells in vitro. Dalian Medical University; 2015.

62. Feng X, Tao Z, Xueqin Z, et al. The inhibitory effect of sevoflurane pretreatment on lung metastasis of Lewis lung cancer cells in mice. J Clin Anesthesiol. 2017;33(1):71-73.

63. Johnson MZ, Crowley PD, Foley AG, et al. Effect of perioperative lidocaine on metastasis after sevoflurane or ketamine-xylazine anaesthesia for breast tumour resection in a murine model. Br J Anaesth. 2018;121(1):76-85. doi:10.1016/j.bja.2017.12.043

64. Kim Y, Yun S, Shin KA, et al. Effects of sevoflurane on lewis lung carcinoma cell proliferation in vivo and in vitro. Medicina. 2021;57(1):45.

65. Hua L, Chengxiang Y, Heng L, Xianjie W, Qiaoling Z. [Effects of isoflurane and sevoflurane on apoptosis and expression of CD44 and CD54 in human lung cancer cell line A549]. Chin J Anesthesiol. 2010;30(04):389, 391. Chinese.

66. Liang H, Gu M, Yang C, Wang H, Wen X, Zhou Q. Sevoflurane inhibits invasion and migration of lung cancer cells by inactivating the p38 MAPK signaling pathway. $J$ Anesth. 2012;26(3):381392. doi:10.1007/s00540-011-1317-y

67. Liang H, Wang HB, Liu HZ, Wen XJ, Zhou QL, Yang CX. The effects of combined treatment with sevoflurane and cisplatin on growth and invasion of human adenocarcinoma cell line A549. Biomed Pharmacother. 2013;67(6):503-509. doi:10.1016/j. biopha.2013.03.005

68. Ciechanowicz S, Zhao H, Chen Q, et al. Differential effects of sevoflurane on the metastatic potential and chemosensitivity of non-smallcell lung adenocarcinoma and renal cell carcinoma in vitro. $\mathrm{Br} J$ Anaesth. 2018;120(2):368-375. doi:10.1016/j.bja.2017.11.066

69. Liang $\mathrm{H}, \mathrm{Gu} \mathrm{MN}$, Yang CX, Wang HB, Wen XJ, Zhou QL. Sevoflurane inhibits proliferation, induces apoptosis, and blocks cell cycle progression of lung carcinoma cells. APJCP. 2011;12 (12):3415-3420.

70. Liang H, Yang CX, Zhang B, et al. Sevoflurane suppresses hypoxia-induced growth and metastasis of lung cancer cells via inhibiting hypoxia-inducible factor-1 $\alpha$. J Anesth. 2015;29(6):821830. doi:10.1007/s00540-015-2035-7

71. Wang L, Wang T, Gu JQ, Su HB. Volatile anesthetic sevoflurane suppresses lung cancer cells and miRNA interference in lung cancer cells. Onco Targets Ther. 2018;11:5689-5693. doi:10. 2147/OTT.S171672

72. Zhang W, Shao X. Isoflurane promotes non-small cell lung cancer malignancy by activating the Akt-mammalian target of rapamycin (mTOR) signaling pathway. Med Sci Monit. 2016;22:4644-4650. doi:10.12659/MSM.898434

73. Ren J, Wang X, Wei G, Meng Y. Exposure to desflurane anesthesia confers colorectal cancer cells metastatic capacity through deregulation of miR-34a/LOXL3. Eur J Cancer Prev. 2021;30 (2):143-153. doi:10.1097/CEJ.0000000000000608

74. Shapiro J, Jersky J, Katzav S, Feldman M, Segal S. Anesthetic drugs accelerate the progression of postoperative metastases of mouse tumors. J Clin Invest. 1981;68(3):678-685. doi:10.1172/JCI110303

75. Hosomi Y, Yokose T, Hirose Y, et al. Increased cyclooxygenase 2 (COX-2) expression occurs frequently in precursor lesions of human adenocarcinoma of the lung. Lung Cancer. 2000;30 (2):73-81. doi:10.1016/S0169-5002(00)00132-X

76. Yoshimatsu K, Altorki NK, Golijanin D, et al. Inducible prostaglandin E synthase is overexpressed in non-small cell lung cancer. Clin Cancer Res. 2001;7(9):2669-2674.

77. Zappavigna S, Cossu AM, Grimaldi A, et al. Anti-inflammatory drugs as anticancer agents. Int $J$ Mol Sci. 2020;21(7):2605. doi:10.3390/ijms21072605

78. Takiuchi T, Blake EA, Matsuo K, Sood AK, Brasky TM. Aspirin use and endometrial cancer risk and survival. Gynecol Oncol. 2018;148(1):222-232. doi:10.1016/j.ygyno.2017.10.026
79. Vogel U, Christensen J, Wallin H, et al. Polymorphisms in genes involved in the inflammatory response and interaction with NSAID use or smoking in relation to lung cancer risk in a prospective study. Mutat Res. 2008;639(1-2):89-100. doi:10.10 16/j.mrfmmm.2007.11.004

80. Hollmann MW, Durieux ME, Fisher D. Local anesthetics and the inflammatory response: a new therapeutic indication? Anesthesiology. 2000;93(3):858-875. doi:10.1097/00000542-200 009000-00038

81. Sun H, Sun Y. Lidocaine inhibits proliferation and metastasis of lung cancer cell via regulation of miR-539/EGFR axis. Artif Cells Nanomed Biotechnol. 2019;47(1):2866-2874. doi:10.1080/ 21691401.2019.1636807

82. Piegeler T, Votta-Velis EG, Bakhshi FR, et al. Endothelial barrier protection by local anesthetics: ropivacaine and lidocaine block tumor necrosis factor- $\alpha$-induced endothelial cell Src activation. Anesthesiology. 2014;120(6):1414-1428. doi:10.1097/ALN.000 0000000000174

83. Grandhi RK, Perona B. Mechanisms of action by which local anesthetics reduce cancer recurrence: a systematic review. Pain Med. 2020;21(2):401-414. doi:10.1093/pm/pnz139

84. Piegeler T, Schlapfer M, Dull RO, et al. Clinically relevant concentrations of lidocaine and ropivacaine inhibit TNFalphainduced vasion of lung adenocarcinoma cells in vitro by blocking the activation of Akt and focal adhesion kinase. Br J Anaesth. 2015;115(5):784-791. doi:10.1093/bja/aev341

85. Piegeler T, Votta-Velis EG, Liu G, et al. Antimetastatic potential of amide-linked local anesthetics: inhibition of lung adenocarcinoma cell migration and inflammatory Src signaling independent of sodium channel blockade. Anesthesiology. 2012;117(3):548559. doi:10.1097/ALN.0b013e3182661977

86. Lucchinetti E, Awad AE, Rahman M, et al. Antiproliferative effects of local anesthetics on mesenchymal stem cells: potential implications for tumor spreading and wound healing. Anesthesiology. 2012;116(4):841-5687. doi:10.1097/ALN.0b0 13e31824babfe

87. Ma XW, Li Y, Han XC, Xin QZ. The effect of low dosage of procaine on lung cancer cell proliferation. Eur Rev Med Pharmacol Sci. 2016;20(22):4791-4795.

88. Freeman J, Crowley PD, Foley AG, et al. Effect of perioperative lidocaine and cisplatin on metastasis in a murine model of breast cancer surgery. Anticancer Res. 2018;38(10):5599-5606. doi:10. 21873/anticanres.12894

89. Vahabi S, Eatemadi A. Effects of anesthetic and analgesic techniques on cancer metastasis. Biomed Pharmacother. 2017;87:1-7. doi:10.1016/j.biopha.2016.12.073

90. Schlagenhauff B, Ellwanger U, Breuninger H, Stroebel W, Rassner G, Garbe C. Prognostic impact of the type of anaesthesia used during the excision of primary cutaneous melanoma. Melanoma Res. 2000;10(2):165-169. doi:10.1097/00008390200004000-00009

91. Xu YJ, Li SY, Cheng Q, et al. Effects of anaesthesia on proliferation, invasion and apoptosis of LoVo colon cancer cells in vitro. Anaesthesia. 2016;71(2):147-154.

92. Byrne K, Levins KJ, Buggy DJ. Can anesthetic-analgesic technique during primary cancer surgery affect recurrence or metastasis? Can J Anaesthes. 2016;63(2):184-192. doi:10.1007/s12630015-0523-8

93. Wang W, Xiao J, Shen S, Wang S, Chen M, Hu Y. Emerging effect of anesthesia on post-operative tumor recurrence and metastasis. J Int Med Res. 2019;47(8):3550-3558. doi:10.1177/ 0300060519861455

94. Wigmore TJ, Mohammed K, Jhanji S. Long-term survival for patients undergoing volatile versus IV anesthesia for cancer surgery: a retrospective analysis. Anesthesiology. 2016;124(1):6979. doi:10.1097/ALN.0000000000000936 
95. Hayasaka K, Shiono S, Miyata S, Takaoka S, Endoh M, Okada Y. Prognostic significance of propofol-based intravenous anesthesia in early-stage lung cancer surgery. Surg Today. 2021;51(8):13001308. doi:10.1007/s00595-020-02216-y

96. Wu WW, Zhang WH, Zhang WY, et al. The long-term survival outcomes of gastric cancer patients with total intravenous anesthesia or inhalation anesthesia: a single-center retrospective cohort study. BMC Cancer. 2021;21(1):1193. doi:10.1186/s128 85-021-08946-7

97. Oh TK, Kim K, Jheon S, et al. Long-term oncologic outcomes for patients undergoing volatile versus intravenous anesthesia for non-small cell lung cancer surgery: a retrospective propensity matching analysis. Cancer Control. 2018;25(1):10732748 18775360. doi: $10.1177 / 1073274818775360$

98. Soltanizadeh S, Degett TH, Gögenur I. Outcomes of cancer surgery after inhalational and intravenous anesthesia: a systematic review. J Clin Anesth. 2017;42:19-25.

99. Jang D, Lim CS, Shin YS, et al. A comparison of regional and general anesthesia effects on 5 year survival and cancer recurrence after transurethral resection of the bladder tumor: a retrospective analysis. BMC Anesthesiol. 2016;16:16. doi:10.1186/ s12871-016-0181-6

100. Zheng W, Li YP, Lai RC, Lu YL, Shen ZW, Wang XD. [Effects of neuraxial block and general anesthesia on tumor metastasis in rats]. Nan Fang Yi Ke Da Xue Xue Bao. 2008;28(12):2218-2220. Chinese.

101. Lee EK, Ahn HJ, Zo JI, Kim K, Jung DM, Park JH. Paravertebral block does not reduce cancer recurrence, but is related to higher overall survival in lung cancer surgery: a retrospective cohort study. Anesth Analg. 2017;125(4):1322-1328. doi:10.1213/ANE. 000000000002342
102. Pi J, Sun Y, Zhang Z, Wan C. Combined anesthesia shows better curative effect and less perioperative neuroendocrine disorder than general anesthesia in early stage NSCLC patients. $J$ Int Med Res. 2019;47(10):4743-4752. doi:10.1177/030006051986 2102

103. Xu Q, Shi NJ, Zhang H, Zhu YM. Effects of combined generalepidural anesthesia and total intravenous anesthesia on cellular immunity and prognosis in patients with non-small cell lung cancer: a comparative study. Mol Med Rep. 2017;16(4):44454454. doi:10.3892/mmr.2017.7144

104. Chen J, Luo F, Lei M, Chen Z. A study on cellular immune function of patients treated with radical resection of pulmonary carcinoma with two different methods of anesthesia and analgesia. J BUON. 2017;22(6):1416-1421.

105. Sessler DI, Ben-Eliyahu S, Mascha EJ, Parat MO, Buggy DJ. Can regional analgesia reduce the risk of recurrence after breast cancer? Methodology of a multicenter randomized trial. Contemp Clin Trials. 2008;29(4):517-526. doi:10.1016/j.cct.2008.01.002

106. Sessler DI. Does regional analgesia reduce the risk of cancer recurrence? A hypothesis. Eur J Cancer Prev. 2008;17(3):269272. doi:10.1097/CEJ.0b013e3282f0c005

107. Sen Y, Xiyang H, Yu H. Effect of thoracic paraspinal blockpropofol intravenous general anesthesia on VEGF and TGF- $\beta$ in patients receiving radical resection of lung cancer. Medicine. 2019;98(47):e18088. doi:10.1097/MD.0000000000018088

108. Wu HL, Tai YH, Chan MY, Tsou MY, Chen HH, Chang KY. Effects of epidural analgesia on cancer recurrence and long-term mortality in patients after non-small-cell lung cancer resection: a propensity score-matched study. BMJ Open. 2019;9(5):e027618. doi:10.1136/bmjopen-2018-027618

\section{Publish your work in this journal}

Cancer Management and Research is an international, peer-reviewed open access journal focusing on cancer research and the optimal use of preventative and integrated treatment interventions to achieve improved outcomes, enhanced survival and quality of life for the cancer patient.
The manuscript management system is completely online and includes a very quick and fair peer-review system, which is all easy to use. Visit http://www.dovepress.com/testimonials.php to read real quotes from published authors. 